\title{
HUBUNGAN DUKUNGAN KELUARGA DENGAN TINGKAT KECEMASAN PADA PASIEN PENYAKIT JANTUNG KORONER
}

\author{
Arabta M. Peraten Pelawi ${ }^{1}$,Yudha Prasetya ${ }^{2}$ \\ Sekolah Tinggi Ilmu Kesehatan Medistra Indonesia ${ }^{l}$ \\ Sekolah Tinggi Ilmu Kesehatan Medistra Indonesia ${ }^{2}$ \\ Email :rasputrabarus@yahoo.com ${ }^{1}$,Yudha.santos@gmail.com ${ }^{2}$
}

\begin{abstract}
ABSTRAK
Angka kejadian penyakit jantung masih nomor satu di dunia, salah satunya penyakit jantung koroner. Pasien yang menderita penyakit jantung memiliki resiko yang dapat membuat penyakitnya semakin parah. Saat seseorang di diagnosa menderita penyakit jantung, respon yang timbul dalam dirinya adalah perasaan cemas dan takut. Dukungan keluarga sangat diperlukan dalam menurunkan tingkat kecemasan pada pasien penyakit jantung koroner. Tujuan dalam penelitian ini adalah menganalisis dukungan keluarga dengan tingkat kecemasan pada pasien penyakit jantung koroner di ruang Wijaya Kusuma RSUD Kota Bekasi Tahun 2015. Desain penelitian ini menggunakan metode deskriptif analitik dengan pendekatan cross sectional, pengambilan sampel dilakukan dengan tehnik puposive sampling yaitu sebanyak 30 responden. Analisa data dilakukan secara bertahap mencakup analisis univariat dan analisis bivariat menggunakan uji statistik chi square. Berdasarkan uji statistik diperoleh nilai $\mathrm{p}$ value $0,018<$ nilai $\alpha$ 0,05. Sehingga $\mathrm{H}_{0}$ ditolak dan $\mathrm{H}_{1}$ diterima artinya ada hubungan dukungan keluarga dengan tingkat kecemasan pada pasien penyakit jantung koroner di ruang Wijaya Kusuma RSUD Kota Bekasi Tahun 2015.
\end{abstract}

\section{Kata Kunci : Dukungan Keluarga, Tingkat Kecemasan, Penyakit Jantung Koroner}

\section{THE RELATIONSHIP OF FAMILY SUPPORT WITH AN ANXIETY IN CORONARY HEART DISEASE PATIENTS}

\begin{abstract}
The incidence of heart disease is still the number one in the world, one of which coronary heart disease. Patients suffering the heart disease have a risk which can make the disease worse. When someone is diagnosed with heart disease, the response that arises in him a feeling of anxiety and fear. Family support is indispensable in reducing the level of anxiety in patients with coronary heart disease. The purpose of this research is to analyze the relations of family support with the level of anxiety in patients with coronary heart disease in Wijaya Kusuma ward at RSUD (District General Hospital of Bekasi) 2015. The design of this research was descriptive analytic with cross-sectional design as approach. The technic of sampling was purposive sampling with 35 respondent. The analyze of this research is continued including the univariate and bivariate analysis using chi-square test. Based on statistical test obtainablep value $0,018<\alpha$ value of 0.05 . So $H_{0}$ is rejected and $H_{1}$ accepted meaning there is a relations family support with the level of anxiety in patients with coronary heart disease in Wijaya Kusuma ward at District General Horpital of Bekasi 2015.
\end{abstract}

Keywords : Family Support, Anxiety Scale, Coronary Heart Diseas 


\section{PENDAHULUAN}

Dengan zaman modern ini pola hidup manusia berubah. Pola hidup yang awalnya sehat berubah perlahan-lahan menjadi tidak sehat. Seiring dengan kemajuan zaman, mulai timbulnya makanan cepat saji dan makanan berkolesterol tinggi, yang saat ini sudah menjadi kebiasaan dan sering dikonsumsi oleh masyarakat sehingga menyebabkan pola hidup yang tidak baik. Pola hidup yang tidak baik ini dapat menimbulkan bahaya bagi kesehatan tubuh kita. Kelebihan kadar kolesterol, khususnya LDL kolesterol dalam jangka panjang, akan menyebabkan penimbunan yang bertambah banyak dari aterosklerosis. Pada tingkat atau kondisi tertentu, dapat memicu terjadinya penyakit jantung koroner dan stroke atau penyakit pembuluh darah otak. ${ }^{1}$

Angka kejadian penyakit jantung masih menjadi penyebab nomer satu di dunia termasuk Indonesia. Pola hidup yang tidak baik adalah salah satu penyebabnya. Semakin bertambahnya usia akan terjadi penumpukan zat-zat racun didalam tubuh. Hal ini akan menimbulkan berbagai macam masalah, salah satunya penyakit jantung koroner. Penyakit jantung koroner dapat menimbulkan komplikasi yang dapat menyebabkan keadaan seseorang semakin bertambah parah. Saat seseorang didiagnosis menderita penyakit kronis, maka respon emosional yang biasanya muncul yaitu penolakan, kecemasan, stress dan depresi. ${ }^{2}$

Cemas adalah perasaan yang timbul dalam diri seseorang terhadap keadaan yang sedang dialaminya. Cemas merupakan respon individu terhadap suatu keadaan yang tidak menyenangkan dan dialami oleh semua makhluk hidup dalam kehidupan sehari-hari. Kecemasan pada individu merupakan pengalaman yang subjektif, dapat memberikan motivasi untuk mencapai sesuatu dan sumber penting dalam usaha memelihara keseimbangan hidup. ${ }^{3}$

Data WHO (2011) menyebutkan bahwa penyakit jantung merupakan penyebab kematian nomor satu di dunia dan $60 \%$ dari seluruh penyebab kematian penyakit jantung adalah penyakit jantung iskemik dan sedikitnya 17,5 juta atau setara dengan 30,0\% kematian di seluruh dunia disebabkan oleh penyakit jantung. Diperkirakan tahun 2030 bahwa 23,6 juta orang di dunia akan meninggal karena penyakit kardiovaskular. ${ }^{4}$
Peran perawat adalah memberikan dukungan dan motivasi kepada keluarga agar selalu mendampingi pasien, memenuhi kebutuhan emosional, spiritual, dan psikososialnya. Sehingga pasien akan merasa diperhatikan dan tidak menimbulkan kecemasan.

Dukungan keluarga adalah sebuah energi positif yang diberikan keluarga kepada anggota keluarganya yang menderita sakit. Dukungan yang diberikan dalam bentuk Emotional Support,

Instrumental Support, Informational Support dan Companionship Support yang dapat meningkatkan aspek emosional dalam kehidupan seseorang. Dengan ini, maka responden merasa dicintai dan diperhatikan, hal ini dapat menurunkan tingkat kecemasan dan dapat menghindari terjadinya komplikasi yang lebih parah. Penderita dengan sindroma koroner akut (SKA) yang merupakan manifestasi klinis akut penyakit jantung koroner, mempunyai risiko untuk mendapat komplikasi yang serius bahkan bisa berujung pada kematian. $^{5}$

Penyakit jantung dengan dukungan keluarga mempunyai hubungan yang erat. Ketidakmampuan pasien penyakit jantung dalam mengaktuliasasikan dirinya secara optimal tanpa dukungan keluarga yang besar dari keluarganya, dapat memperburuk kondisi mental dan psikologisnya. Dalam sebuah penelitian yang dilakukan oleh Hartika Pratiwi, 2009. Desain penelitiannya menggunakan kualitatif dengan judul "Social Support pada Lansia Penderita Penyakit Jantung Koroner". Penelitiannya dilakukan di RS. H. Adam Malik Medan dengan jumlah informan sebanyak 2 orang. Hasil dari penelitiannya menyatakan bahwa Social Support memiliki hubungan yang erat dengan kesehatannya dan keberadaan Social Support memberi keuntungan bagi kesehatan seseorang. ${ }^{6}$

Responden yang diberikan Social Support dari keluarga dan orang terdekatnya dapat mempercepat proses pemulihan dan dapat meningkatkan aktualisasi dirinya dalam sosialisasinya didalam keluarga maupun di lingkungan masyarakat. Dalam hal ini, dukungan keluarga diperlukan untuk menjaga kesehatan pasien penyakit jantung dari masalah-masalah yang dapat timbul. Kecemasan pada pasien penyakit jantung 
dapat berpengaruh bagi kesehatannya dan dapat beresiko menimbulkan masalah-masalah yang baru akan muncul. Seperti disebutkan dalam penelitian Made Widiyanti, (2013) menyatakan bahwa cemas juga memiliki keterkaitan dengan hasil negatif dari jantung pada spektrum penyakit jantung. ${ }^{7}$

Hasil studi pendahuluan yang dilakukan peneliti pada tanggal 27 Oktober 2015 didapatkan hasil jumlah pasien yang mengalami penyakit jantung koroner selama 3 bulan terakhir sebanyak 83 pasien dan pasien setiap minggunya sebanyak 4-5 pasien. Dari hasil wawancara oleh seorang responden didapatkan hasil responden merasa cemas dengan penyakitnya karena tak kunjung sembuh dan sudah 4 kali berobat ke rumah sakit. Keluarga sudah memberikan motivasi, tetapi responden tetap merasa cemas dan putus asa. Kunjungan yang dilakukan oleh keluarga responden sangat jarang, karena sibuk dengan pekerjaannya masing-masing. Di rumah sakit responden hanya di temani oleh istrinya, karena anaknya ada yang masih kecil. Hal ini membuat responden pernah mengatakan kepada peneliti bahwa banyak beban pikiran yang dialaminya saat ini.

Tujuan penelitian ini adalah mengetahui bagaimana hubungan dukungan keluarga terhadap tingkat kecemasan pada pasien penyakit jantung koroner di Ruangan Rawat Inap Wijaya Kusuma RSUD Kota Bekasi, tahun 2015.

\section{METODE}

Penelitian ini menggunakan desain penelitian deskriptif analitik dengan pendekatan cross sectional yaitu penelitian yang dilakukan untuk mempelajari dinamika korelasi antara variabel independen dan dependen dengan cara melakukan observasi pada subjek penelitian hanya sekali saja dalam waktu yang bersamaan. ${ }^{8}$ Populasi dalam penelitian ini adalah seluruh pasien yang mengalami penyakit jantung koroner yang ada di RSUD Kota Bekasi. Tehnik sampling dalam penelitian ini menggunakan tehnik purposive sampling yaitu peneliti beranggapan seseorang memiliki informasi yang dibutuhkan dalam penelitiannya. ${ }^{8}$ Sampel dalam penelitian ini adalah pasien yang mengalami penyakit jantung koroner yang sedang di rawat inap di ruang wijaya kusuma RSUD Kota Bekasi.Instrumen pengambilan data dalam penelitian ini menggunakan skala Likert untuk variabel dukungan keluarga pada pasien penyakit jantung koroner dan lembar observasi menggunakan HRS-A (Hamilton Rating Scale for Anxiety) untuk variabel kecemasan pasien penyakit jantung koroner.Tehnik analisa dalam penelitian ini menggunakan tehnik analisa bivariat yaitu analisis yang dilakukan terhadap dua variabel yang diduga berhubungan atau berkorelasi. ${ }^{13}$ Analisa yang digunakan adalah Uji Chi Square.

HASIL

A. Analisa Univariat

1. Distribusi Frekuensi Dukungan Keluarga pada Pasien Penyakit Jantung Koroner di Ruang Wijaya Kusuma RSUD Kota Bekasi Tabel 1

Distibusi Frekuensi Dukungan Keluarga pada Pasien Penyakit Jantung Koroner di Ruang Wijaya Kusuma RSUD Kota Bekasi Tahun 2015

\begin{tabular}{lcc}
\hline $\begin{array}{c}\text { Dukungan } \\
\text { Keluarga }\end{array}$ & $\begin{array}{c}\text { Frekuensi } \\
(\mathbf{N})\end{array}$ & $\begin{array}{c}\text { Presentase } \\
(\mathbf{\%})\end{array}$ \\
\hline Baik & 15 & 50,0 \\
Cukup & 13 & 43,3 \\
Kurang & 2 & 6,7 \\
\hline \multicolumn{1}{c}{ Total } & $\mathbf{3 0}$ & $\mathbf{1 0 0 , (} \quad 2$ \\
\hline
\end{tabular}

Berdasarkan tabel 5.1 ditas dapat diketahui dari $30 \quad(100,0 \%)$ responden, menunjukkan bahwa responden yang memiliki dukungan keluarga "baik" sebanyak 15 orang $(50,0 \%)$, responden yang memiliki dukungan keluarga "cukup" sebanyak 13 orang $(43,3 \%)$ dan responden yang memiliki dukungan keluarga 'kurang" sebanyak 2 orang $(6,7 \%)$.

2. Distribusi Frekuensi Tingkat Kecemasan pada Pasien Penyakit Jantung Koroner di Ruang Wijaya Kusuma RSUD Kota Bekasi 
Tabel 2

Distribusi Frekuensi Tingkat Kecemasan pada Pasien Penyakit Jantung Koroner di Ruang Wijaya Kusuma RSUD Kota Bekasi

\begin{tabular}{|c|c|c|}
\hline $\begin{array}{c}\text { Tingkat } \\
\text { Kecemasan }\end{array}$ & $\begin{array}{c}\text { Frekuensi } \\
(\mathbf{N})\end{array}$ & $\begin{array}{c}\text { Presentase } \\
(\%)\end{array}$ \\
\hline Ringan & 14 & 46,7 \\
\hline Sedang & 9 & 30,0 \\
\hline Berat & 5 & 16,6 \\
\hline Sangat & 2 & 6,7 \\
\hline \multicolumn{3}{|l|}{ Berat } \\
\hline Total & 30 & 100,0 \\
\hline
\end{tabular}

Berdasarkan tabel 5.1 diatas dapat diketahui dari $30 \quad(100,0 \%)$ responden, menunjukkan bahwa responden yang memiliki tingkat "kecemasan ringan" sebanyak 14 orang $(46,7 \%)$, responden yang memiliki tingkat "kecemasan sedang" sebanyak 9 orang $(30,0 \%)$, responden yang memiliki tingkat "kecemasan berat" sebanyak 5 orang (16,6\%), dan responden yang memiliki tingkat "kecemasan sangat berat" sebanyak 2 orang $(6,7 \%)$. sedang", dan 1 responden $(6,7 \%)$ mengalami tingkat "kecemasan berat". Sebanyak 13 responden $(100,0)$ yang mendapat dukungan keluarga "cukup" yaitu sebanyak 3 responden $(23,3 \%)$ mengalami tingkat "kecemasan ringan", 5 responden $(34,3 \%)$ mengalami tingkat "kecemasan sedang", 4 responden $(30,7 \%)$ mengalami tingkat "kecemasan berat", dan 1 responden $(7,7 \%)$ mengalami tingkat "kecemasan sangat berat".

Sebanyak 2 responden $(100,0)$ yang mendapat dukungan keluarga "kurang" yaitu sebanyak 1 responden $(50,0 \%)$ mengalami tingkat "kecemasan sedang", dan 1 responden $(50,0 \%)$ mengalami tingkat "kecemasan sangat berat"

Hasil uji statistik chi square diperoleh $p$ value sebesar 0,018. Dapat disimpulkan bahwa pvalue $(0,018 \%)<$ nilai $\alpha(0,05)$, hal ini menunjukan bahwa $\mathrm{H} 0$ ditolak, dimana artinya ada hubungan dukungan keluarga dengan tingkat kecemasan pada pasien penyakit jantung koroner yang dirawat inap di ruang wijaya kusuma RSUD Kota Bekasi.

Tabel 3

Hubungan Dukungan Keluarga dengan Tingkat Kecemasan pada Pasien Penyakit Jantung Koroner di Ruang Wujaya Kusuma RSUD Kota Bekasi Tahun 2015

\begin{tabular}{|c|c|c|c|c|c|c|c|c|c|c|c|}
\hline \multicolumn{12}{|c|}{ Tingkat Kecemasan } \\
\hline \multirow[t]{2}{*}{$\begin{array}{l}\text { Dukungan } \\
\text { Keluarga }\end{array}$} & \multicolumn{2}{|c|}{$\begin{array}{c}\text { Kecemasan } \\
\text { Ringan }\end{array}$} & \multicolumn{2}{|c|}{$\begin{array}{c}\text { Kecemasan } \\
\text { Sedang }\end{array}$} & \multicolumn{2}{|c|}{$\begin{array}{c}\text { Kecemasan } \\
\text { Berat }\end{array}$} & \multicolumn{2}{|c|}{$\begin{array}{c}\text { Kecemasan } \\
\text { Sangat Berat }\end{array}$} & \multicolumn{2}{|c|}{ Total } & $\begin{array}{c}p \\
\text { Value }\end{array}$ \\
\hline & $\mathrm{N}$ & $\%$ & $\mathrm{~N}$ & $\%$ & $\mathrm{~N}$ & $\%$ & $\mathrm{~N}$ & $\%$ & $\mathrm{~N}$ & $\%$ & \\
\hline Baik & 11 & 73,3 & 3 & 20,0 & 1 & 6,7 & 0 & 0,0 & 15 & 100,0 & \\
\hline Cukup & 3 & 23,3 & 5 & 34,3 & 4 & 30,7 & 1 & 7,7 & 13 & 100,0 & \\
\hline Kurang & 0 & 0,0 & 1 & 50,0 & 0 & 0,0 & 1 & 50,0 & 2 & 100,0 & 0,018 \\
\hline Total & 14 & 46,6 & 9 & 30,0 & 5 & 16,6 & 2 & 6,7 & 30 & 100,0 & \\
\hline
\end{tabular}

\section{B. Analisis Bivariat}

Berikut ini akan dijelaskan hasil analisa tentang hubungan dukungan keluarga dengan tingkat kecemasan pada pasien penyakit jantung di ruang wijaya kusuma RSUD Kota Bekasi Tahun 2015.

Berdasarkan tabel 5.3 dapat diketahui bahwa dari 15 responden $(100,0)$ yang mendapat dukungan keluarga "baik" yaitu sebanyak 11 responden $(73,3 \%)$ mengalami tingkat "kecemasan ringan", 3 responden $(20,0 \%)$ mengalami tingkat "kecemasan

\section{PEMBAHASAN}

Dukungan keluarga merupakan ketersediaan sumber daya yang memberikan kenyamanan fisik dan psikologis yang didapat melalui pengetahuan bahwa individu tersebut dicintai, diperhatikan, dihargai oleh orang lain dan ia juga merupakan anggota dalam suatu kelompok yang berdasarkan kepentingan bersama. ${ }^{9}$

Berdasarkan hasil penelitian yang dilakukan oleh peneliti menyatakan bahwa dari 30 responden, terdapat 15 responden $(50,0 \%)$ yang mendapatkan dukungan keluarga kategori "baik". 
Berdasarkan hasil penelitian diatas, bahwa pengaruh dukungan keluarga sangat diperlukan untuk anggota keluarga yang sedang mengalami penyakit jantung. Adapun dukungan keluarga menurut House (Smet, 1994) dalam Setiadi, 2008) setiap bentuk dukungan keluarga mempunyai ciri-ciri antara lain: informatif, perhatian emosional, bantuan instrumental dan bantuan penilaian. Bentukbentuk dukungan keluarga tersebut akan menciptakan dukungan yang baik kepada anggota keluarganya dan menjadikan anggota keluarga dalam keadaan nyaman, tentram dan harmonis. ${ }^{10}$

Dalam semua tahap, dukungan sosial keluarga menjadikan keluarga mampu berfungsi dengan berbagai kepandaian dan akal, sehingga akan meningkatkan kesehatan dan adaptasi mereka dalam kehidupan. ${ }^{10}$

Dukungan keluarga dapat memberikan keuntungan bagi kesehatan seseorang yang mengalami sakit. Hal ini sesuai dengan teori (Taylor, 2009) yang menyatakan sebagaimana mestinya social support dapat menolong pasien penyakit jantung untuk dapat memulihkan kembali keadaan penderita penyakit ini, mengurangi distress dan menyembuhkan gejala-gejala penyakit jantung koroner, khususnya saat penderita berada di rumah sakit. ${ }^{6}$

Dukungan keluarga terdiri dari 4 indikator yang diteliti dalam penelitian ini yang meliputi dukungan emosional, dukungan intrumental, dukungan informasional dan dukungan penghargaan. Semua aspek dukungan keluarga tersebut saling berhubungan erat. Efek dari dukungan sosial terhadap kesehatan dan kesejahteraan berfungsi bersamaan. Secara lebih spesifik, adanya dukungan sosial keluarga yang adekuat terbukti berhubungan dengan menurunnya mortalitas, lebih mudah sembuh dari sakit, menjaga fungsi kognitif, fisik dan kesehatan emosi. Disamping itu, pengaruh positif dari dukungan sosial keluarga adalah pada penyesuaian terhadap kejadian dalam kehidupan yang penuh dengan stres. ${ }^{10}$

Seseorang akan menderita gangguan cemas manakala yang bersangkutan tidak mampu mengatasi stressor psikososial yang dihadapinya. Tetapi pada orang-orang tertentu meskipun tidak ada stressor psikosisial, yang bersangkutan menunjukan kecemasan juga. ${ }^{11}$

Faktor pencetus kecemasan mungkin berasal dari sumber internal atau eksternal. Ada dua kategori faktor pencetus kecemasan, yaitu ancaman terhadap integritas fisik dan terhadap sistem diri. ${ }^{12}$

Pasien yang menderita penyakit jantung koroner pasti mengalami perasaan cemas, maka diperlukan peran keluarga dalam mendukung anggota keluarganya yang sakit agar dapat mempengaruhi penurunan tingkat kecemasan. Tingkat kecemasan yang dialami oleh seorang pasien yang mengalami penyakit jantung koroner dapat dipengaruhi oleh seberapa besar dukungan keluarga yang diberikan terhadap anggotanya yang mengalami sakit, karena dukungan keluarga salah satu faktor yang dapat mempengaruhi tingkat kecemasan pasien penyakit jantung koroner.

Dukungan keluarga yang diperoleh pasien penyakit jantung koroner di RSUD Kota Bekasi berasal dari keluarga dan kerabatnya yaitu istri dan anak, ayah, ibu, rekan kerja, tetangga maupun mertua. Hal ini sesuai dengan teori (Pratiwi, 2009) menyatakan bahwa social support diterima individu melalui interaksi sosial dalam kehidupannya secara spontan dengan orang-orang yang berada disekitarnya, misalnya: anak, istri, suami, rekan kerja dan kerabat. ${ }^{6}$

Hasil analisa peneliti, perasaan cemas adalah suatu hal yang wajar bagi seseorang yang mengalami penyakit jantung koroner. Perasaan cemas baik ringan hingga panik yang dirasakan individu tersebut tergantung pada kesiapan individu dan keluarga. Kesiapan itu sendiri dapat berupa dukungan keluarga baik emosional, instrumental, informasional dan penilaian yang diberikan keluarga kepada anggota keluarganya yang sedang mengala 4 sakit. Dapat dilihat dari hasil penelitian bah semakin baik dukungan keluarga terhac... pasien penyakit jantung koroner, maka akan berbanding lurus dengan tingkat kecemasannya yakni pasien mengalami kecemasan ringan. Dapat dilihat dari hasil olah data, sebanyak 15 responden yang memberikan dukungan keluarga baik, 11 responden diantaranya mengalami tingkat kecemasan ringan. Peneliti mengambil kesimpulan bahwa dukungan keluarga memiliki pengaruh besar dalam menurunkan tingkat kecemasan anggota keluarganya yang mengalami penyakit jantung koroner.

\section{PENUTUP}

Berdasarkan hasil analisis dan pembahasan yang telah diuraikan sebelumnya, 
maka hasil penelitian yang telah dilakukan tentang "Hubungan Dukungan Keluarga Dengan Tingkat Kecemasan Pada Pasien Penyakit Jantung Koroner Di Ruang Rawat Inap Wijaya Kusuma RSUD Kota Bekasi Tahun 2015", maka peneliti dapat mengambil kesimpulan yaitu:

1. Distribusi frekuensi dukungan keluarga pada pasien penyakit jantung koroner, jumlah tertinggi dengan kategori "baik".

2. Distribusi frekuensi tingkat kecemasan pada pasien penyakit jantung koroner, jumlah tertinggi dengan kategori "ringan".

3. Ada hubungan antara dukungan keluarga dengan tingkat kecemasan pada pasien penyakit jantung koroner.

\section{DAFTAR PUSTAKA}

1. Anies. 2015. Kolesterol dan Penyakit Jantung Koroner. Jogjakarta : ARRUZZ MEDIA

2. Sholichah, D.R. (2009). Hubungan antara Dukungan Sosial dengan Derajat Depresi padaPenderita Diabetes Melitus dengan Komplikasi. Fakultas Kedokteran Universitas Sebelas Maret Surakarta.

3. Suliswati. (2005). KonsepDasar Keperawatan Kesehatan Jiwa. Jakarta: EGC

4. Sri Sumarti, 2010. Faktor-faktor Risiko Penyakit Jantung Koroner pada Usia Dewasa Muda yang Dirawat Di Instalasi Jantung dan Pembuluh Darah Rumah Sakit Dokter Kariadi. Semarang : Universitas diponegoro.

5. Himpunan Mahasiswa Epidemiologi FKM USU,2008. Epidemiologi PJK. Link

from:http://repository.usu.ac.id/bitstre am/123456789/40275/4/Chapter\%20I I.pdf

6. Pratiwi, H. (2009). Social SupportPada Lansia Penderita Penyakit Jantung Koroner.Fakultas Psikologi Universitas Sumatera Utara, 114.

7. Widiyanti, M. (2013). Hubungan Antara Depresi, Cemas dan Sindrom Koroner Akut.Fakultas Kedokteran
Universitas Udayana Sanglah

Denpasar, 10.

8. Dharma, K, K. 2011. Metodologi Penelitian Keperawatan Pedoman Melaksanakan dan Menerapkan Hasil Penelitian. Jakarta. Trans Info Media

9. Indriani \& Asmuji. 2014. Buku Ajar Keperawatan Maternitas. Yogyakarta: AR-RUZZ MEDIA

10. Setiadi. (2008). Konsep \& Proses Keperawatan Keluarga. Yogyakarta: Graha Ilmu.

11. Hawari. 2011. Manajemen Stres, Cemas dan Depresi. Jakarta : Balai Penerbit FKUI

12. Titik Lestari, S. (2015). Kumpulan Teori Untuk Kajian Pustaka Penelitian Kesehatan. Yogyakarta: Nuha Medika.

13. Notoatmodjo. 2010. Metodologi Penelitian Kesehatan. Jakarta. PT. Rineka Cipta 